\title{
Environmental learning about flood disaster in university: Students HOTS for preliminary analysis to develop DIFMOL model
}

\author{
Henita Rahmayanti ${ }^{*}$, Ilmi Zajuli Ichsan ${ }^{1}$, Sylvira Ananda Azwar ${ }^{2}$, Setia Damayanti ${ }^{3}$, Erni \\ Suharini ${ }^{4}$, and Edi Kurniawan ${ }^{4}$ \\ ${ }^{1}$ Department of Environmental Education, Universitas Negeri Jakarta, Indonesia \\ ${ }^{2}$ Department of Transportation, Universitas Negeri Jakarta, Indonesia \\ ${ }^{3}$ Department of Architecture, Universitas Pancasila, Indonesia \\ ${ }^{4}$ Department of Geography Education, Universitas Negeri Semarang, Indonesia
}

\begin{abstract}
Environmental education during a pandemic is something that must be focused especially on natural disasters. One of the skills needed to solve natural disasters is Higher Order Thinking Skills (HOTS). The purpose of this study was to describe student HOTS to develop a Disaster Mitigation of Flood based on the Online Learning (DIFMOL) model. The research method used descriptive with data collection techniques using surveys. The results showed that the student's HOTS score was still in the very low category (33.09). This makes DIFMOL need to be developed for students, especially in aspects related to HOTS, which are still weak for aspects of flood disasters. Environmental education innovation is important to improve students' ability to overcome environmental problems. DIFMOL in this case, acts as an environmental education innovation related to the disaster that can be developed. This study concludes that students' HOTS scores are still in the very low category and need improvement. DIFMOL is suggested to be developed in the next research.
\end{abstract}

\section{Introduction}

Environmental education is an important thing to do in the 21 st century. This is due to the increasing number of environmental problems that occur today, especially for urban areas. Many components of society do not have sufficient knowledge to solve problems in their environment. This is because the community does not sufficiently understand many environmental components. Problems such as poor waste management, environmental pollution problems, and disaster problems become bad things in urban areas. Education to the public is important in overcoming this environmental problem [1-5]. One of them is related to flood disaster mitigation efforts that students can do, especially during the pandemic Coronavirus Disease 2019 (COVID-19).

Students have an important role in overcoming environmental problems. This is because students have many programs that can be implemented in the community. This program is

\footnotetext{
*Corresponding author: henita.rahmayanti@unj.ac.id
} 
also one of which can be implemented by students. The scientific background of Engineering students who study various types of construction will contribute to overcoming various environmental problems [6-8]. Environmental problems that must be solved require Higher Order Thinking Skills (HOTS). This is because HOTS ability enables students to analyze problems, then evaluate the problem and create solutions to these problems [9-13]. Environmental problems are becoming more complex due to the COVID19 pandemic situation.

The research that has been done in previous research is related to the description of the student's HOTS score. The results showed that the students' HOTS scores are still in the low category [9]. Besides, various learning models and strategies have been developed that aim to increase HOTS $[13,14]$. This is an innovation in environmental education to develop a model in the classroom in learning. One model that can be developed is Disaster Mitigation of Flood based on Online Learning (DIFMOL). Previous research has carried out a general analysis of student attitudes in overcoming various flood disasters [15]. The results showed that the students' attitude in dealing with floods was already supportive and following the disaster management program's policies. However, in this study, the HOTS score description has not been carried out specifically for Engineering Faculty students.

Based on the description, it is necessary to conduct further analysis of Engineering faculty students' HOTS ability to overcome various environmental problems, especially floods. The DIFMOL model being developed can be an innovation of context with flooding that occurs in urban areas. This model will be a model that can provide education to the wider community regarding efforts to solve environmental problems. Based on this, the purpose of this study was to describe the HOTS of Engineering Faculty students as the basis for the development of DIFMOL for use in the Engineering Faculty.

\section{Method}

This research was conducted in July 2020. The method used is descriptive. The data collection technique used was a survey using google form. The HOTS instrument indicator of Analyze, Evaluate, Create which is developed into a further indicator. The indicators of the HOTS instrument for engineering students can be seen in the table below.

Table 1. Student HOTS indicators related to flooding.

\begin{tabular}{|l|l|l|}
\hline Aspect & Indicators & Item \\
\hline Analyze (C4) & $\begin{array}{l}\text { Analyzing the impact of a river sediment dredging program to } \\
\text { mitigate flooding }\end{array}$ & 1,2 \\
\hline Analyze (C4) & $\begin{array}{l}\text { Analyzing the impact of using plastic bags related to flooding } \\
\text { during the COVID-19 outbreak }\end{array}$ & 3,4 \\
\hline Evaluate (C5) & $\begin{array}{l}\text { Evaluating the effectiveness of expanding urban green areas as } \\
\text { water catchment areas }\end{array}$ & 5,6 \\
\hline Evaluate (C5) & $\begin{array}{l}\text { Criticizing drainage and garbage dumps in densely populated } \\
\text { houses to prevent flooding and COVID-19 }\end{array}$ & 7,8 \\
\hline Create (C6) & $\begin{array}{l}\text { Creating a program to encourage other students to prevent } \\
\text { flooding }\end{array}$ & 9,10 \\
\hline Create (C6) & $\begin{array}{l}\text { Creating an activity plan to invite the public to prevent flooding } \\
\text { and prevent the transmission of COVID-19 }\end{array}$ & 11,12 \\
\hline
\end{tabular}

Note: Indicators adapted from Ichsan et al. [10]

The data analysis used is to compare the various average scores that have been obtained. The average score is then analyzed descriptively, and it will be seen on which indicators and items have low scores. The results of the data analysis were then interpreted in the HOTS score category. 
Table 2. Categories of students' HOTS scores.

\begin{tabular}{|l|l|}
\hline Categories & Interval Score \\
\hline Very High & $\mathrm{X}>81,28$ \\
\hline High & $70,64<\mathrm{X} \leq 81,28$ \\
\hline Moderate & $49,36<\mathrm{X} \leq 70,64$ \\
\hline Low & $38,72<\mathrm{X} \leq 49,36$ \\
\hline Very Low & $\mathrm{X} \leq 38,72$ \\
\hline
\end{tabular}

Note: Indicators adapted from Ichsan et al. [10]

\section{Results and discussion}

This study indicates that the students' HOTS scores are still in the very low category. This becomes the basis for the development of the DIFMOL model in the Engineering faculty. The lowest score can be seen in Table 3 below.

Table 3. Average student HOTS score for each item

\begin{tabular}{|l|l|l|}
\hline No & Item & Average \\
\hline 1 & Analyze policies related to river normalization & 3.22 \\
\hline 2 & Analyzing the impact of river dredging & 2.81 \\
\hline 3 & Analyzing the impact of using plastic bags on flooding during COVID-19 & 3.72 \\
\hline 4 & Analyzing a paid plastic bag policy during COVID-19 & 3.35 \\
\hline 5 & $\begin{array}{l}\text { Give an opinion about a densely populated house that does not have a green } \\
\text { area (garden) }\end{array}$ & 2.92 \\
\hline 6 & $\begin{array}{l}\text { Give your solutions and opinions so that the green area target can be achieved } \\
\text { as a whole }\end{array}$ & 3.12 \\
\hline 7 & $\begin{array}{l}\text { Give your criticism about the narrow drainage and its impact on the spread of } \\
\text { Covid-19 }\end{array}$ & 3.43 \\
\hline 8 & $\begin{array}{l}\text { Give your criticism and opinion about the floods caused by the accumulation } \\
\text { of garbage about the spread of COVID-19 }\end{array}$ & 3.42 \\
\hline 9 & $\begin{array}{l}\text { Creating a program to prevent flooding in the environment around areas that } \\
\text { are often hit by floods }\end{array}$ & 3.57 \\
\hline 10 & $\begin{array}{l}\text { Creating an innovative program so that students can become examples in the } \\
\text { implementation of maintaining cleanliness to prevent flooding }\end{array}$ & 3.06 \\
\hline 11 & $\begin{array}{l}\text { Create a resume that contains invitations and facts about the importance of } \\
\text { preventing floods to maintain health to minimize the spread of COVID-19 }\end{array}$ & 3.59 \\
\hline 12 & $\begin{array}{l}\text { Creating an innovative program with a unique name so that people want to } \\
\text { prevent flooding, especially during the COVID-19 pandemic. }\end{array}$ & 3.50 \\
\hline Raw Score & 39.71 \\
\hline Average score for all items (interval score 0-100) & 33.09 \\
\hline Category & Very Low \\
\hline
\end{tabular}

Note: Indicators adapted from Ichsan et al. [10]

As seen from each indicator, the HOTS score of Engineering students shows that the first and third indicators are the lowest. This showed that the DIFMOL model developed for Engineering students must be strengthened on indicators regarding rivers and the expansion of green areas. It can be seen more clearly than the average score obtained was only 3.02 (see Table 4).

Table 4. Average student HOTS score for each indicator

\begin{tabular}{|l|l|l|}
\hline Aspect & Indicators & Average \\
\hline Analyze (C4) & $\begin{array}{l}\text { Analyzing the impact of a river sediment dredging program to } \\
\text { mitigate flooding }\end{array}$ & 3.02 \\
\hline Analyze (C4) & Analyzing the impact of using plastic bags related to flooding & 3.53 \\
\hline
\end{tabular}




\begin{tabular}{|l|l|l|}
\hline & during the COVID-19 outbreak & 3.02 \\
\hline Evaluate (C5) & $\begin{array}{l}\text { Evaluating the effectiveness of expanding urban green areas } \\
\text { as water catchment areas }\end{array}$ & 3.42 \\
\hline Evaluate (C5) & $\begin{array}{l}\text { Criticizing drainage and garbage dumps in densely populated } \\
\text { houses to prevent flooding and COVID-19 }\end{array}$ & 3.31 \\
\hline Create (C6) & $\begin{array}{l}\text { Creating a program to encourage other students to prevent } \\
\text { flooding }\end{array}$ & $\begin{array}{l}\text { Creating an activity plan to invite the public to prevent } \\
\text { flooding and prevent the transmission of COVID-19 }\end{array}$ \\
\hline Create (C6)
\end{tabular}

Meanwhile, when viewed from the aspects of $\mathrm{C} 4, \mathrm{C} 5$, and C6, the score with the lowest average is at $\mathrm{C} 5$ (see Table 5). This showed that Engineering students have not been able to maximize their ability to think critically. It is necessary to make various efforts to overcome the problem of this low capability of C5.

Table 5. Average HOTS score for each aspect

\begin{tabular}{|l|l|}
\hline Aspect & Average \\
\hline Analyze (C4) & 3.28 \\
\hline Evaluate (C5) & 3.22 \\
\hline Create (C6) & 3.43 \\
\hline
\end{tabular}

Based on the research results, it was found that the HOTS score was still relatively low. This showed that the HOTS score of Engineering students needs to be improved. This HOTS score can be improved by various learning innovations based on HOTS. Students become one of society's components whose role is needed to overcome environmental problems [16-19]. So that efforts to solve environmental problems based on HOTS need to be more focused. Students can develop broader knowledge related to environmental education. Existing facilities at the university, such as equipment for making a miniature building, for example, can be used for disaster simulations.

The relationship between HOTS and disaster when it is closely related to disaster is a complex environmental problem [20-22]. This complex environmental problem must be solved with HOTS capabilities. Problems such as obstruction of waterways cause flooding as well as problems with at least water catchment areas. This problem can be solved with students' HOTS ability, especially to be able to analyze problems. After the problem can be analyzed, the next stage is to evaluate and provide responses related to the problem. Finally, after all these problems have been successfully analyzed and evaluated, the final step is to create a solution. Environmental problems that must be faced are becoming more complicated due to the COVID-19 pandemic. Environmental education must be accompanied by efforts to improve human resources' quality from various components ranging from the development of teaching materials, media, and other learning tools [2329].

DIFMOL, in this case, has a role as a learning tool to improve HOTS abilities. This is following the HOTS description obtained in this study. DIFMOL developed for Engineering students requires an environmental approach and also needs to be strengthened from an environmental perspective. This is done so that the environmental education provided is following the context of 21 st-century learning. Things that need to be strengthened in 21 st-century learning are related to the aspects of solving problems and finding solutions to these problems. Various tools developed must also be based on technological developments to support various learning in the 21 st century. The development of environment learning can impact students and the community to keep the environment [30-37]. 


\section{Conclusion}

Based on this study's results, the HOTS score of the students is still in the very low category. This shows that student HOTS still needs to be improved according to the development of the 21st century. DIFMOL, in this case, can be developed as a solution in overcoming the low HOTS of students in overcoming flood problems. The suggestion of this research is to be able to develop DIFMOL in further research.

\section{Acknowledgements}

Thank you for Research Grants from Universitas Negeri Jakarta in 2020. Research Scheme Research University Program (Penelitian hibah unggulan universitas) number: 31/KOMP$\mathrm{UNJ} / \mathrm{LPPM} / \mathrm{V} / 2020$.

\section{References}

1. H. Rahmayanti, V. Oktaviani, Y. Syani, The implementation of smart trash as smart environment concept, E3S Web of Conferences, 74, 06003 (2018) https://doi.org/10.1051/e3sconf/20187406003

2. A. Harahap, A. Zuhriyah, H. Rahmayanti, N. Nadiroh, Relationship between knowledge of green product, social impact and perceived value with green purchase behavior, E3S Web of Conferences, 74, 04002 (2018) https://doi.org/10.1051/e3sconf/20187404002

3. H. Rahmayanti, E. Maulida, E. Kamayana, The role of sustainable urban building in industry 4.0, Journal of Physics: Conference Series, 1387, 1, 012050 (2019) https://doi.org/10.1088/1742-6596/1387/1/012050

4. V. H. Storr, S. Haeffele-Balch, L. E. Grube, Social capital and social learning after Hurricane Sandy, Review of Austrian Economics, 30, 4, 447-467 (2017) https://doi.org/10.1007/s11138-016-0362-z

5. R. Muthukrishnan, J. E. Kelley, Depictions of sustainability in children's books, Environment, Development and Sustainability, 19, 3, 955-970 (2017) https://doi.org/10.1007/s10668-016-9778-7

6. R. Arthur, F. A. Rouf, H. Rahmayanti, A. Maulana, Plumbing work competence instrument in the field of civil engineering, Journal of Physics: Conference Series, 1402, 2, 022019 (2019) https://doi.org/10.1088/1742-6596/1402/2/022019

7. H. Murzi, A. Mazzurco, I. Pikaar, B. Gibbes, Measuring development of environmental awareness and moral reasoning: A case-study of a civil engineering course, European Journal of Engineering Education, 44, 6, 954-968 (2019) https://doi.org/10.1080/03043797.2019.1566300

8. S. Maslen, J. Hayes, Case based learning among practicing engineers: design, facilitation and lessons learned, Cognition, Technology and Work, 1996 (2019) https://doi.org/10.1007/s10111-019-00569-0

9. I. Z. Ichsan, H. Rahmayanti, HOTSEP: Revised Anderson's Taxonomy in environmental learning of COVID-19, European Journal of Educational Research, 9, 3, 1257-1265 (2020) https://doi.org/10.12973/eu-jer.9.3.1257

10. I. Z. Ichsan, D. V. Sigit, M. Miarsyah, A. Ali, W. P. Arif, T. A. Prayitno, HOTS-AEP: Higher order thinking skills from elementary to master students in environmental learning, European Journal of Educational Research, 8, 4, 935-942 (2019) https://doi.org/10.12973/eu-jer.8.4.935

11. I. Z. Ichsan, D. V. Sigit, M. Miarsyah, A. Ali, T. Suwandi, T. Titin, Implementation supplementary book of green consumerism: improving students hots in environmental 
learning, European Journal of Educational Research, 9, 1, 227-237 (2020) https://doi.org/10.12973/eu-jer.9.1.227

12. A. C. Saputri, S. Sajidan, Y. Rinanto, A. Afandi, N. M. Prasetyanti, Improving students' critical thinking skills in cell-metabolism learning using stimulating higher order thinking skills model, International Journal of Instruction, 12, 1, 327-342 (2019) https://doi.org/10.29333/iji.2019.12122a

13. H. Husamah, D. Fatmawati, D. Setyawan, OIDDE learning model: Improving higher order thinking skills of biology teacher candidates, International Journal of Instruction, 11, 2, 249-264 (2018) https://doi.org/10.12973/iji.2018.11217a

14. G. A. M. Saido, S. Siraj, D. Dewitt, O. S. Al-Amedy, Development of an instructional model for higher order thinking in science among secondary school students: A fuzzy delphi approach, International Journal of Science Education, 40, 8, 847-866 (2018) https://doi.org/10.1080/09500693.2018.1452307

15. H. Rahmayanti, I. Z. Ichsan, S. A. Azwar, E. Kurniawan, B. Irawan, T. Titin, Indonesian Student Environmental Attitude of flood during COVID-19: DIFMOL Education Model in 21st Technology, International Journal of Advanced Science and Technology, 29, 5, 6245-6253 (2020) http://sersc.org/journals/index.php/IJAST/article/view/15628

16. B. Tanujaya, J. Mumu, G. Margono, The Relationship between Higher Order Thinking Skills and Academic Performance of Student in Mathematics Instruction, International Education Studies, 10, 11, 78-85 (2017) https://doi.org/10.5539/ies.v10n11p78

17. X. He, T. Hong, L. Liu, J. Tiefenbacher, A comparative study of environmental knowledge, attitudes and behaviors among university students in China, International Research in Geographical and Environmental Education, 20, 2, 91-104 (2011) https://doi.org/10.1080/10382046.2011.564783

18. D. Dani, Sustainability as a Framework for Analyzing Socioscientific Issues, International Electronic Journal of Environmental Education, 1, 2, 113-128 (2011)

19. D. Saribas, Z. D. Kucuk, H. Ertepinar, Implementation of an environmental education course to improve pre-service elementary teachers' environmental literacy and selfefficacy beliefs, International Research in Geographical and Environmental Education, 26, 4, 311-326 (2017) https://doi.org/10.1080/10382046.2016.1262512

20. F. M. A. Khan, M. Masood, The Effectiveness of an Interactive Multimedia Courseware with Cooperative Mastery Approach in Enhancing Higher Order Thinking Skills in Learning Cellular Respiration, Procedia - Social and Behavioral Sciences, 176, 977-984 (2015) https://doi.org/10.1016/j.sbspro.2015.01.567

21. M. Barak, Y. J. Dori, Enhancing higher order thinking skills among inservice science teachers via embedded assessment, Journal of Science Teacher Education, 20, 5, 459474 (2009). https://doi.org/10.1007/s10972-009-9141-z

22. C. Murphy, L. Bianchi, J. McCullagh, K. Kerr, Scaling up higher order thinking skills and personal capabilities in primary science: Theory-into-policy-into-practice, Thinking Skills and Creativity, 10, 173-188 (2013) https://doi.org/10.1016/j.tsc.2013.06.005

23. M. Paristiowati, T.Hadinugrahaningsih, A. Purwanto, P. A. Karyadi, Analysis of students' scientific literacy in contextual-flipped classroom learning on acid-base topic, Journal of Physics: Conference Series, 1156, 1, 012026 (2019) https://doi.org/10.1088/1742-6596/1156/1/012026

24. A. Sahronih, A. Purwanto, M. S. Sumantri, The effect of interactive learning media on students' science learning outcomes, ACM International Conference Proceeding Series, 20-24 (2019) https://doi.org/10.1145/3323771.3323797 
25. A. Purwanto, I. Z. Ichsan, P. W. P.Gomes, M. M. Rahman, I. Irwandani, ESBOR during COVID-19: Analysis students attitude for develop 21st century environmental learning, Journal of Sustainability Science and Management, 15, 7 (2020)

26. R. S. D. Wihardjo, S.Syarifullah, A. Purwanto, Y. Nurani, Influence of inquiry learning strategy and locus of control on students' environmental knowledge, Universal Journal of Educational Research, 8, 3, 764-768 (2020) https://doi.org/10.13189/ujer.2020.080305

27. D. V. Sigit, M. Miarsyah, R. Komala, A. Suryanda, I. Z. Ichsan, R. Fadrikal, EECN: Analysis, potency, benefit for students knowledge and attitude to conserve mangroves and coral reefs, International Journal of Instruction, 13, 1, 125-138 (2020) https://doi.org/10.29333/iji.2020.1318a

28. M. Miarsyah, D. V. Sigit, I. Z. Ichsan, R. Fadrikal, M. Suprapto, Lekersmulia: Improving indonesian students' environmental responsibility using multimedia in environmental learning, International Journal of Scientific and Technology Research, $8,12,1639-1643$ (2019)

29. E. P. Azrai, D. V. Sigit, E. Heryanti, I. Z. Ichsan, Y. P. Jajomi, R. Fadrikal, Green consumerism among students: A survey in campus, Journal of Physics: Conference Series, 1317, 1, 012200 (2019). https://doi.org/10.1088/1742-6596/1317/1/012200

30. A. J. Khoiriyah, H. Husamah, Problem-based learning: creative thinking skills, problem-solving skills, and learning outcome of seventh grade students, JPBI (Jurnal Pendidikan Biologi Indonesia), 4, 2, 151-160 (2018)

https://doi.org/10.22219/jpbi.v4i2.5804

31. D. V. Sigit, E. P. Azrai, E. Heryanti, I. Z. Ichsan, Y. P. Jajomi, R. Fadrikal, Development green consumerism e-book for undergraduate students (gc-ebus) as learning media in environmental learning, Indian Journal of Public Health Research and Development, 10, 8, 2026-2031 (2019) https://doi.org/10.5958/0976$\underline{5506.2019 .02152 .1}$

32. M. Miarsyah, R. Rusdi, N. D. Aryani, I. Z. Ichsan, MEBA: Development androidbased ecosystem module for senior high school students, Indian Journal of Public Health Research and Development, 10, 8, 2114-2118 (2019) https://doi.org/10.5958/0976-5506.2019.02168.5

33. H. Rahmayanti, I. Z. Ichsan, V. Oktaviani, Y. Syani, W. Hadi, G. Marhento, Environmental attitude for smart city technology: Need assessment to develop smart trash in environmental education, International Journal of Advanced Science and Technology, 29, 3, 8374-8383 (2020)

http://sersc.org/journals/index.php/IJAST/article/view/9872

34. H. Rahmayanti, V. Oktaviani, Y. Syani, Development of sorting waste game android based for early childhood in environmental education, Journal of Physics: Conference Series, 1434, 1, 012029 (2020) https://doi.org/10.1088/1742-6596/1434/1/012029

35. H. Rahmayanti, S. Ananda, Analysis of environmental infrastructure sustainability of low cost apartment: Rusunawa in Jakarta, International Journal of Social Ecology and Sustainable Development, 8, 2, 1-13 (2017) https://doi.org/10.4018/IJSESD.2017040101

36. Y. H. Sipahutar, H. Rahmayanti, R. Achmad, H. K. Ramli, M. R. Suryanto, R. B. Pratama, Increase in cleaner production environment in the fish processing industry through work motivation and fisherman women's leadership, IOP Conference Series: Earth and Environmental Science, 399, 1, 012119 (2019) https://doi.org/10.1088/1755$1315 / 399 / 1 / 012119$

37. Y. H. Sipahutar, H. Rahmayanti, R. Achmad, M. R. Suryanto, R. R. Ramandeka, M. R. Syalim, R. B. Pratama, A. N. Rahmi, P. Astrianti, G. Mila, The influence of women's leadership in the fishery and cleaner production of fish processing industry on the 
effectiveness of coastal preservation program in Tangerang, IOP Conference Series:

Earth and Environmental Science, 404, 1, 012061 (2019) https://doi.org/10.1088/1755$\underline{1315 / 404 / 1 / 012061}$ 